\title{
On the eliminating attempts toward Šesták-Berggren equation
}

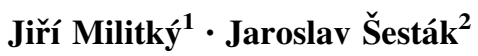

Received: 4 January 2016/ Accepted: 11 September 2016

(C) Akadémiai Kiadó, Budapest, Hungary 2016

\begin{abstract}
Some recent commentaries doubt the originality of Šesták-Berggren equation even though it received until today almost eight hundred citation responses. The worth of SB equation is examined in terms of general logistic equation showing its divergent philosophical strategy from dissimilar orthodox geometrical modeling in kinetics. The use of appended terms 'truncated' and 'extended' is questioned.
\end{abstract}

Keywords Šesták-Berggren equation · Logistics ·

Kinetics · Truncated · Extended

A simple relation consisting of two interrelated parameters $\alpha$ and opposite $(1-\alpha)$ is known since the middle of eighteenth century as a logistic equation [1] beneficial to describe various forms of dissemination (diesis, reactions) $[2,3]$. It reasonably involves interpretation of $\alpha$ as a kind of mortality involving the reactant disappearance and the complementary fertility of a reactant yet ready to proceed in the response to $(1-\alpha)$ [4]. Such a logistic model makes possible to stay away from the orthodox classification of a reacting system employing conventional models based on a set of perfect geometrical (Euclidean) bodies (mostly ideal spheres) [5-7].

One hundred years later still unacquainted of its logistic past the $\alpha$ relation was enriched by two arbitrary exponents

Jaroslav Šesták

sestak@fzu.cz

1 Technical University in Liberec, Studentská str. 2, 46117 Liberec, Czech Republic

2 University of West Bohemia, Universitní str. 8, 30114 Plzeň, Czech Republic $n$ and $m$ while introduced in the thermoanalytical practice [8] and consequently coined by readers as the ŠestákBerggren (SB) equation exhibiting recently as many as 790 citation responses (SCOPUS).

Not long ago this approach [9] became a center of dialogue $[10,11]$ whether such a SB designation is appropriate instigating a question what is behind the recent struggle to confuse such a widely cited SB equation and why this well-established label should be eliminated from the citation awareness. There are two rational answers: First, the SB equation has a suspicious and unspecified mathematical background [9], and second, there might endure a personal motivation. So let us analyze both.

Already the introducing sentence in the Burnham commentary [10] citing 'It is simply illogical that both should have the same name' is unsubstantiated because the both relations

$a^{\mathrm{n}}(1-a)^{\mathrm{m}}\{\log (1-a)\}^{\mathrm{p}}$

and

$a^{\mathrm{n}}(1-a)^{\mathrm{m}}$

have the same origin [8] encompassing their particular sequential logic $(p \rightarrow 0)$. Thus far, Eq. (1). is possessing three general exponents $n, m, p$, and in the original paper [8], it was further specified to optimally comprise only two parameters $n, m$ (Eq. 2) as a most reliable and consistent form of a logistic approach [4, 8]. It was similarly discriminated in [8], the table on page 11, row 5, citing: 'Nucleation (Eqs. 18, 25), latter stages of growth of nuclei (Eqs. 25, 26), diffusion (Eq. 31) thus consequently called by the public in an ensuing literature as the SB equation. Interestingly, the similar table was iterated in Ref. [12]. Both the above equations were concurrently named by readers as the SB equation as e.g. in Ref. [13] and other 
papers referenced in [9]. The above particulars are not listed in the critique $[10,11]$, indicating that the original paper [8] was not read in all detail (or was even purposefully unread).

Logistic equations [4-7] provide an alternative insight into the reaction interfaces which can be identified with an underlying principle of defects [4] and their propagation alike illnesses dissemination [2, 3]. Logistics may thus become the roots of antagonism of those who habitually operate with idealistic archetypes [14].

Fault-finder [11] persistently imposed the term 'truncated' (as a mathematical portrayal of a poorly adjusted logistic equation) which has the devaluing sense and would perhaps better fit his usage of an absurd form of constitutive equating (cf. Eq. 8 on p. 411 of Ref. [14]) anticipated for a fictitious description of the extent of reaction, $\alpha$, as a function of partial derivatives.

The instigation of SB equation $[8,9]$ did not account for its previous logistic origin [1] then still unknown [10]. Though authors' English [9] is called poor [10], which is understandable being not his mother tongue. Not observing basic algebraic rules the author [9], on the other hand, illogically proposed name likewise labeled as the 'extended' Proat-Tomkins equation, which was originally published with the unit exponents only. Such an extended portrayal violets the common sense when ridiculously expanding the initial two simple parameters $(m=1$ and $n=1$ of Eq. 2) to numberless figures which is similar to an absurd expending $e^{1}$ to innumerable $e^{\mathrm{n}}$ (just to take a personal pleasure of being different).

The paper history [8] was given in detail in [9] emphasizing that it should not have any particular label and its name coining was a matter of luck of readers act in response. However, the SB equation also brought along some confusion as if it would have been unwelcome in the chronicles of Thermochimica Acta though it has become its best cited paper. The subsequent Šimon's article taking note of its forty years anniversary [15] was published with large obstacles and Heels manuscript [16] dealing with a detailed mathematical analysis of SB equation, and its consequences were rejected at all.

The Russian book by Akulov [17] and Prodan [18], the absence of which in original [8] was criticized [10, 11], presents Eq. 2 with arbitrary exponents rather vague without a deeper model inspection as executed in [8]. It subsists as an extension of Akulov autogenesis model [19] where $n$ and $m$ are made equal to one afterward arriving to an optional case with both exponents equal to $2 / 3$, analogically to the interface reaction models by Kolmogorov [20]. This early Russian books [17, 18] were not even quoted in the first response to SB paper [8] by Gorbachev [21], by coincidence Russian, despite that he had a full access approach to Russian literature nor the books [17, 18]

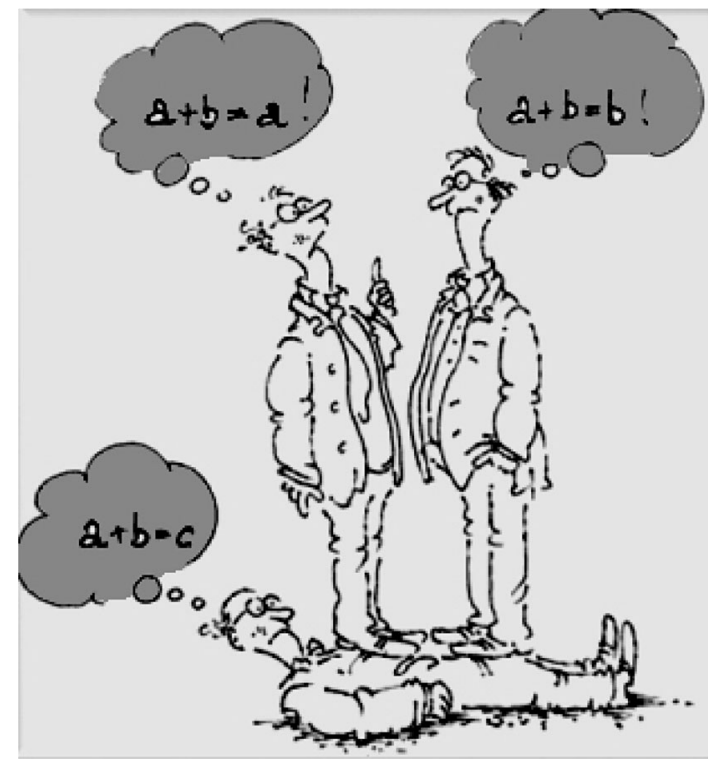

Fig. 1 Occasionally it is good to remember that sometimes petty nomenclature contradictions can destroy even the great personalities of mathematics

were mentioned in the recent historical survey by Gavrichev and Holba [22].

The SB equation keeps alive recently as thoroughly analyzed in terms of JMAK equation in the respected Journal of Non-Crystalline Solids [23], and its present citation worth of about eight hundred citation responses increases every year by about another forty. This is not a bad reputation of such a labeled equation having its own internet Web page ${ }^{1}$ showing its annual and cumulative citation responding. Thus, it is not surprise that papers $[8,9]$ may perhaps become an object of rivalry.

Moreover, who gives to the challenger [11] rights to discriminate what are unsubstantiated, suspicious and scholarly not purposed thoughts or what is correct or incorrect to publish in scientific journals' [24]. The authors are responsible for their published figures that can be criticized but not subjected to individually forced exclusion. The degree of criticism is different in various territories, and the criticizer as a former Russian emigrant should be aware that such tough criticism is normal in the East and journals are international subjects (Fig. 1).

Acknowledgements The results were developed within the CENTEM project, reg. no. CZ.1.05/2.1.00/03.0088, that is co-funded by the ERDF as part of the MEYS-Ministry of Education, Youth and Sports OP RDI Program, and in the follow-up sustainability stage, supported through the CENTEM PLUS (LO 1402) by financial aid of above MEYS under the "National Sustainability Program I."

\footnotetext{
${ }^{1}$ http://libra.msra.cn/Publication/26613183/study-of-the-kinetics-ofthe-mechanism-of-solid-state-reactions-at-increasing-temperatures.
} 


\section{References}

1. Verhulst PF. Recherches mathématiques sur la loi d'accroisement de la population. Mem. Acad. R. Bruxelles. 1844;18:1-10.

2. Peleg M, Corradini MG, Normand MD. The logistic Verhulst model for sigmoidal microbial growth curves revisited. Food Res. Int. 2007;40:808-18.

3. Avramov I. Kinetics of distribution of infections in network. Phys. A. 2007;379:615.

4. Avramov I, Šesták J. Generalized kinetics of overall phase transition explicit to crystallization. J. Therm. Anal. Calorim. 2014;118:1715-20.

5. Militký J, Šesták J. Evaluation and interpretation of nonisothermal kinetic models. Thermochim. Acta. 1992;203:31-7.

6. J. Šesták, Modeling of Reaction Mechanism: Use of Euclidian and Fractal Geometry, Chapter 10 in His Book: Science of Heat and Thermophysical Studies: a Generalized Approach to Thermal Analysis (Elsevier, Amsterdam 2005), pp. 276-314

7. M. Meloun, J. Militký, Nonlinear Regression Models, Chapter 8 in their book: Statistical Data Analysis: a practical guide (Woodhead, Cambridge, 2011), pp. 667-768

8. Šesták J, Berggren G. Study of the kinetics of the mechanism of solid-state reactions at increasing temperature. Thermochim. Acta. 1971;3:1-13.

9. Šesták J. Šesták-Berggren equation: now questioned but formerly celebrated-what is right. J. Therm. Anal. Calorim. 2016. doi:10. 1007/s10973-015-4998-x.

10. Burnham AK. Response to statements by Professor Šesták concerning logistic equations in kinetics. J. Thermal. Anal. Calorim. 2016. doi:10.1007/s10973-015-5216-6.

11. Vyazovkin S. The truncated Šesták-Berggren equation is still the Šsták-Berggren equation, just truncated. J. Thermal. Anal. Calorim. 2016. doi:10.1007/s10973-015-5215-7.

12. Xu Q, Zhang H, Li H, Zhao S, Wan L, Yan Y. Pyrolysis kinetics mechanism analysis of sawdust by Šesták-Berggren function. Energy Sour. Part A. 2013;35:936-44.
13. Munteanu G, Segal E. Šesták-Berggren function in temperature programmed reduction. J. Therm. Anal. Calorim. 2010;101:89-95.

14. Vyazovkin S, Wight CA. Kinetic concepts of thermally stimulated reactions in solids: a view from a historical perspective. Int. Rev. Phys. Chem. 2000;19:45-60.

15. Šmon P. Forty years of the Šesták-Berggren equation. Thermochim. Acta. 2011;520:156-7.

16. N.G. Heal, An explanation of the Šesták-Berggren equation. Submitted to Thernochim. Acta (2000) but rejected for publication

17. Akulov NS. Basics of Chemical Dynamics. Moscow: Moscow State University; 1940. p. 56 (in Russian).

18. Prodan AE. Heterogeneous Chemical Reactions. (Minsk, Nauka i Technika 1965), p. 22 (in Russian)

19. Akulov NS. On the genesis of chemical reactions. Comp. Rend. Acad. Sci. URSS. 1940;28:135-8 (in Russian).

20. Kolmogorov A. Statistical theory for the recrystallization of metals. Akad. Nauk SSSR. Izv. Ser. Matem. 1937;1:355 (in Russian).

21. Gorbachev VM. Aspects of Šesták’s generalized equation applied to thermal analysis kinetic. Zh. Fiz. Khim. USSR. 1977;51:1100 (in Russian).

22. Gavrichev KS, Holba P. International conference on thermal analysis and calorimetry in Russia 2013 and hot topic discussion. J. Therm. Anal. Calorim. 2015;119:1453-8.

23. Arshad MA, Maaroufi A. Relationship between Johnson-MehlAvrami and Šesták-Berggren models in the kinetics of crystallization in amorphous materials. J. Non Cryst. Solids. 2015;413:53-8.

24. Šesták J, Fiala J, Gavrichev SK. Evaluation of the professional worth of scientific papers, their citation responding and the publication authority of Journal of Thermal Analysis and Calorimetry (presented at RCTAC, St Petersburg, September 2016). J. Therm. Anal. Calorim (submitted). 